\title{
Microbiological and physicochemical criteria of fruit juices sold in Egypt: Incidence of spore-forming bacteria
}

\author{
Samir Ahmed Marghany Mahgoub ${ }^{1 *}$, Gehan Abdallah El-Shourbagy ${ }^{2}$ \\ ${ }^{1}$ Agricultural Microbiology Department, Faculty of Agriculture, Zagazig University, Zagazig 44511, Egypt; ${ }^{2}$ Food Science Department, Faculty of \\ Agriculture, Zagazig University, Zagazig 44511, Egypt
}

\section{A B S T R A C T}

\begin{abstract}
The quality and safety of several commercial fruit juices $(n=360)$ sold in Egypt were assessed in this study by analyzing quantitative microbiological and physicochemical parameters, and incidence of spore-forming bacteria. Three commercial brands e.g. apple (A4 \& A5) and cocktail (C4) samples contained Coliforms and presumptive Escherichia coli; mean 1.30 to 1.85 log $_{10}$ CFU/ml. Staphylococcus aureus were absent in all the samples tested. Alicyclobacillus acidoterrestris, Bacillus coagulans, B. licheniformis and $B$. mycoides species were the predominant organisms isolated from A4, guava (G4), mango (M3) and C4 juice samples. The A4, G4, M3 and C4 samples contained of $2.36-3.23 \log _{10} \mathrm{CFU} / \mathrm{ml}$ from total bacterial counts and yeast/mold counts. The TSS and total sugars were within expected ranges. However, the titratable acidity, $\mathrm{pH}$, and color were varied. Thus, this study emphasizes the need for the accelerated and sharp detection of spore forming bacteria in juice products, and provides information on the quality attributes of some brands of fruit.
\end{abstract}

Keywords: Alicyclobacillus; Bacillus; Food safety; Fruit juices; Physicochemical analysis

\section{INTRODUCTION}

Fruit juices are well appreciated by consumers because of their taste, nutritional value, and availability at the right time. Also, they are an important part of the modern diet in many countries (Vantarakits et al., 2011). In spite of these potential benefits offered, concerns over their safety and quality have been raised. Food and Drug Administration (FDA) estimated that about 140 juice related illnesses that can be prevented yearly. Therefore, the labeling rules for juice products have increased the awareness of consumers of the hazards of drinking untreated juice (FDA, 2001). There is now increasing concern from pathogenic microorganisms among regulators regarding the safety of juices due to the potential ability of these pathogens to survive during the manufacturing process. Soil, faeces, food ingredients and processing chain might be sources of contamination in the food chain. Sporulation of spore forming bacteria is occurring in very diverse environments (Carlin, 2011). Until recently, fruit juice considered to be susceptible to spoilage by acidophilic microorganisms. However, the acidic $\mathrm{pH}$ and heat treatment applied during manufacturing of fruit juices led to prevent the spoilage by lactic acid bacteria, yeasts-molds and mycelial fungi (Wineen, (2006)). There are several researches of fungal contamination in fruit juices are dwell in the literature (Mendoza et al., 1982; Parish and Higgins, 1989; Kurtzman et al., 2001; Tournas et al., 2006 and Parish, 2009). In addition, contamination by spore-forming, thermophilic and acidophilic bacteria such as Alicyclobacillus acidoterrestris and Bacillus spp. resulted in increased number of spoilage cases of fruit juices and their products (Chang and Kang, 2004). The incidence of Alicyclo. acidoterrestris has been reported in fruit juices e.g. pear juice, white grape, aloe vera, apples, citrus and mango (McIntyre et al., 1995; Walls and Chuyate, 1998; Wineen, 2006; Durak et al., 2010; Steyn et al., 2011). The worldwide requirements with regard to the presence of Alicyclobacillus spp. in juices is changeable and approximately $60 \%$ of importers require their absence for purchasing the products. The spread of Alicyclobacillus spp. in a container of fruit juice received in the destination country may result in economic losses and leads to distrust by buyers to suppliers

\section{${ }^{*}$ Corresponding author:}

Samir Ahmed Marghany Mahgoub, Agricultural Microbiology Department, Faculty of Agriculture, Zagazig University, Zagazig 44511, Egypt.

E-mail: mahgoubsamir@gmail.com, Tel/Fax: +20552287567 
(Oteiza, et al., 2011). This bacterium is known to produce chemicals that induce sour and off-flavors in fruit juice (Walls and Chuyate, 1998); with important implications for the relevant industries (Walker and Phillips, 2008). Fruit juices are generally treated at temperatures of about $95^{\circ} \mathrm{C}$ for $2 \mathrm{~min}$ (Komitopoulou et al., 1999); however spores have been shown to survive such heat treatments (Splittstoesser et al., 1994) and surviving spores can germinate and grow at $\mathrm{pH}<4$ (Walker and Phillips, 2008) in fruit juice, leading to spoilage. Bacillus licheniformis survive pasteurization process and cause spoilage of juices, producing compounds associated with disinfectant-like odour. Other bacteria were isolated from 51 juices samples $(42.5 \%)$ and fungi from 78 juices samples (65\%). Escherichia coli O157:H7 was detected in four of the juices samples (3.34\%), and Staphylococcus aureus was detected in four different samples (3.34) (Vantarakis, et al., 2011). Juices have become frequent vehicle for transmitting pathogens, such as E. coli O157:H7 (APHA, 2001), Salmonella (CDC, 1997) and Cryptosporidium (Buchanan, et al., 1998).

In Egypt, Few data are available concerning the microbiological quality of the fruit juices. Due to their potential in the international markets, it is necessary to evaluate if they are accomplishing the quality requirements, and to know the microbial load that can affect their safety. For this purpose, samples of national products were carefully purchased and analyzed for physical, chemical and microbiological characteristics. In this respect, Alicyclobacillus spp., Bacillus spp., E. coli, Stapbylococcus spp. and yeasts should be monitored as potential spoilage microorganisms in fruit juices.

\section{MATERIALS AND METHODS}

\section{Samples collection}

A total of 360 fruit juices samples $(200 \mathrm{ml})$, packaged in carton were carefully purchased during the first month of their production in 2013. The packaged products are belonging to six commercial brands $(1,2,3,4,5$ and 6). Six different juices or nectar products (apple (A), guava nectar $(\mathrm{G})$, mango nectar $(\mathrm{M})$, pineapple juice $(\mathrm{P})$, orange $(\mathrm{O})$ and cocktail $(\mathrm{C})$ ) from each brand were randomly sampled from supermarket chains in Zagazig, Egypt. About 36 samples from each brand and 10 samples from each kind of juice were purchased during the period of study. All were labeled as having been made from natural fruits. Samples were stored at refrigeration temperature $\left(5^{\circ} \mathrm{C}\right)$ from the time of purchase to delivery to the Laboratory of Microbiology and Laboratory of Food Science, Faculty of Agriculture, Zagazig University, Zagazig, Egypt. Once the samples were received, the juices type, source of fruits, location of manufacture, and purchase location were recorded, and each sample was coded and then analyzed for microbiological and physicochemical parameters.

\section{Microbiological analysis Microbial count}

Fruit juices samples were analyzed for total bacterial count (TBC), total spore-forming bacteria count (SFC), coliforms (CF), E. coli, yeasts \& molds (YM), and Staphylococcus spp. (ST) according to standard methods of APAH (2001). Briefly, $25 \mathrm{ml}$ of fruit juices were weighed into sterile bags and homogenized in $225 \mathrm{ml}$ of buffered peptone water (BPW, $0.1 \% \mathrm{w} / \mathrm{v} \mathrm{pH} 7.2)$. Serial dilutions were made in BPW. The TBC were determined by the spread plating technique according to standard methods onto Plate Count agar (PCA, Merck, 1.05463) and incubated at $30{ }^{\circ} \mathrm{C}$ for $48 \mathrm{~h}$. The SFC were counted onto PCA after immersed the serial dilution on water bath at $80{ }^{\circ} \mathrm{C}$ for $10 \mathrm{~min}$. Alicyclobacillus spp. was counted onto Potato Dextrose agar (PDA) at $\mathrm{pH} 3.7$ and incubated at $50{ }^{\circ} \mathrm{C}$ for 3 days. Staphylococci determined on Baired Parker agar (Biolife, Milano, Italy) supplemented with egg yolk and the plates incubated at $37^{\circ} \mathrm{C}$ for $48 \mathrm{~h}$; $\mathrm{St}$. aureus detected by examining the plates of Baired Parker for typical black, convex colonies, with a light halo, which were tested for positive coagulase reaction (Bactident Coagulase, Biolife). Total coliforms enumerated on Violet-Red Bile agar (VRBA, Biolife, Milano, Italy) using a double layer of the medium at $35^{\circ} \mathrm{C}$ for $24 \mathrm{~h}$ (Christen et al. 1992). For E. coli, the detection was done by using the selective Chromo Cult Coliform agar (Merck KGaA, Germany) according to the manufacturer's instructions and confirmed with Kovac's indole reagent. Yeasts and molds were determined onto Rose Bengal Chloramphenicol agar (RBCA, Lab M, 36) supplemented with chloramphenicol, X009 and the plates were incubated at $25^{\circ} \mathrm{C}$ for 5 days. All plates were examined for typical colony types and morphological characteristics associated to each culture medium.

\section{Identification of the spore-forming bacteria}

The bacterial isolates onto PDA at $\mathrm{pH} 3.7$ and PCA, after immersed the serial dilution on water bath at $80{ }^{\circ} \mathrm{C}$ for 10 min were identified according to Bergey's Manual of Systematic Bacteriology (Holt, et al. 1994). The tests included Gram stain, endospore formation, catalase test, starch hydrolysis (Mishra and Behera, 2008), VogesProskauer (VP) test (Rhodehamel, et al. 1998) and motility test (Dey, et al. 1998). After these identification tests the isolates were cultured and then confirmed by Egyptian Culture Collection at Cairo (MERCIN) Ain Shams University (Cairo, Egypt).

\section{Physicochemical analysis $\mathrm{pH}$ and titratable acidity}

The $\mathrm{pH}$ of samples was assessed by $\mathrm{pH}$ meter $(\mathrm{pH} 211$ HANNA instruments Inc. Woonsocket- USA made in 
Romania). An amount of $10 \mathrm{ml}$ of juice was mixed with $40 \mathrm{ml}$ distilled water. The electrode was inserted into the mixture and measurements taken under continuous stirring. Titratable acidity was determined in juices samples expressed as lactic acid (\%) according to the standard methods (AOAC, 1997).

\section{Total soluble solids (TSS) and sugar content}

The total soluble solids (TSS) level of the juice was determined using a digital refractometer (AR-2008, Kruss, Germany) according the method of Daramola and Asunni, (2007). The measured value was expressed as ${ }^{\circ}$ Brix. Sugar content was determined according to AOAC (1997). A substantial amount of extracted juice was dropped onto the refractometer. The reading shown was the reading of the total soluble solids for the juice.

\section{Colour}

The colour measurement was performed by using a Color Flex E Z Spectrophotometer (45/0 LAN, 45॰/0, Large, USA) with reference to illuminant D 65 and a $10^{\circ}$ observer angle to obtain values of $\mathrm{L}^{*}, \mathrm{a}^{*}, \mathrm{~b}^{*}$. The $\mathrm{L}^{*}$ value measures the lightness and changes from 0 (black) to 100 (white). The $a^{*}$ values measures the redness where it changes from $-a^{*}$ (greenness) to $+a^{*}$ redness). Lastly, $b^{*}$ measures the yellowness; - $b^{*}$ (blueness) to $+b^{*}$ (yellowness). A $50 \mathrm{ml}$ sample of juice was placed in an optical cell with a path length of $20 \mathrm{~mm}$ (Hunter Lab setting) for the measurement. The values of $a^{*}$ and $b^{*}$ were used to calculate the parameters of the colour appearance (Bernalte et al., 2003).

Physicochemical determinations of the samples were analyzed in triplicate. For each replication, duplicate measurements were conducted and the results averaged.

\section{Statistical analysis}

The numerical results are given as means and standard deviations (SD) using SPSS software (SPSS for Windows), with " $n$ " being the number of juices samples. Data were statistically analyzed using ANOVA variance analysis through the general linear models (GLM) procedure of the statistical analysis system software (SPSS for Windows). Least significant differences were used to separate means at $p<0.05$.

\section{RESULTS AND DISCUSSION}

\section{Hygiene indicators in fruit juices samples}

All 360 juice samples were tested for microbial growth on six different culture media (PCA, PDA, RBCA, VRBA, KGaA and Baird Parker) to determine hygiene quality of fruits juices samples in Zagazig, Egypt after manufacturing and within their shelf-life (Fig. 1). Total bacterial counts
(TBC), total coliforms counts and E. coli were considered as hygiene indicators to evaluate the microbiological profile of food samples. Additionally, they are typically measured to assess the effectiveness of sanitation practices and potential fecal contamination on products (USDAFSIS, 1996). The results indicated that St. aureus were not detected in any of the samples tested. Fruit juices should not contain organisms that can cause disease for human being (EC, 2013). However, three commercial brands that produced apple and cocktail juices contained coliforms and presumptive E. coli; A4, A5 and C4 samples mean 1.30 to $1.85 \log _{10} \mathrm{CFU} / \mathrm{ml}$.

The level of E. coli and total coliform counts in A4, A5 and C4 were all found to be significantly higher than all samples (Fig. 1). Additionally, cocktail juice from C4 exhibited significantly higher E. coli, coliforms, TBC, YM and SF counts compared with C1, C2, C3, C5 and C6. Thus, a number of the tested samples did not meet the Egyptian guidelines and EC (2013) for the microbiological quality of juices. Recently, Vantarakis, et al., (2011) observed that the fruit juices samples sold in Greece were negative for Lactobacillus, Clostridium perfrigens, Salmonella spp., B. cereus, total coliforms, E. coli, and Listeria monocytogenes. However, in Libya St. aureus was detected in $8(5.5 \%)$, Streptococcus spp. in $4(2.7 \%)$, coliforms $(22.6 \%)$, E. coli (none were of serogroup O157) in $3(2.1 \%)$, Klebsiella pneumonia in 17 (11.6\%), Aeromonas spp. in 3 (2.1\%), and Pseudomonas aeruginosa in $6(4.1 \%)$ in the juices tested (Ghenghesh, et al., 2005). The TBC and yeast/mold counts in A4, A4, G4, G5, M3, M4 and C4 juices samples were contained 2.18 to 2.56 $\log _{10} \mathrm{CFU} / \mathrm{ml}$. This result is in agreement with Vantarakis, et al., (2011) in Greece, about 11 juices samples (9.1\%), the total number of microorganisms detected was as high as 125 colony forming units $\left(2.09 \log _{10} \mathrm{CFU} / \mathrm{ml}\right)$. This is due to the acidic nature of fruit juices which probably favours the growth of yeasts. In USA, Tournas et al. (2006) during their studies on the mycological quality of packaged fruit salads and pasteurized fruit juices sold in the Washington, DC Metro area and they reported that $22 \%$ of the fruit juice samples tested showed fungal contamination. Yeasts were the predominant contaminants ranging from $<1.0$ to $6.83 \log _{10} \mathrm{CFU} / \mathrm{ml}$. Also, Ndife et al. (2013) evaluated the microbial quality of different brands of orange juice in Nigerian market and stated that the viable microbial counts for the juice samples were very low (1.0x10- to $\left.5.2 \times 10^{2} \mathrm{CFU} / 100 \mathrm{ml}\right)$. A new system in sanitations and sterilization should be generally introduced into the juice industry sector to improve the hygiene quality of fruit juices especially the countries with variable in weather. However, the level of all microbial tested in pineapple and orange juice was under the detection limit. These were juices with $\mathrm{pH}$ below 4.0. The $\mathrm{pH}$ and acidity of pineapple and orange juices examined range between 2.9 


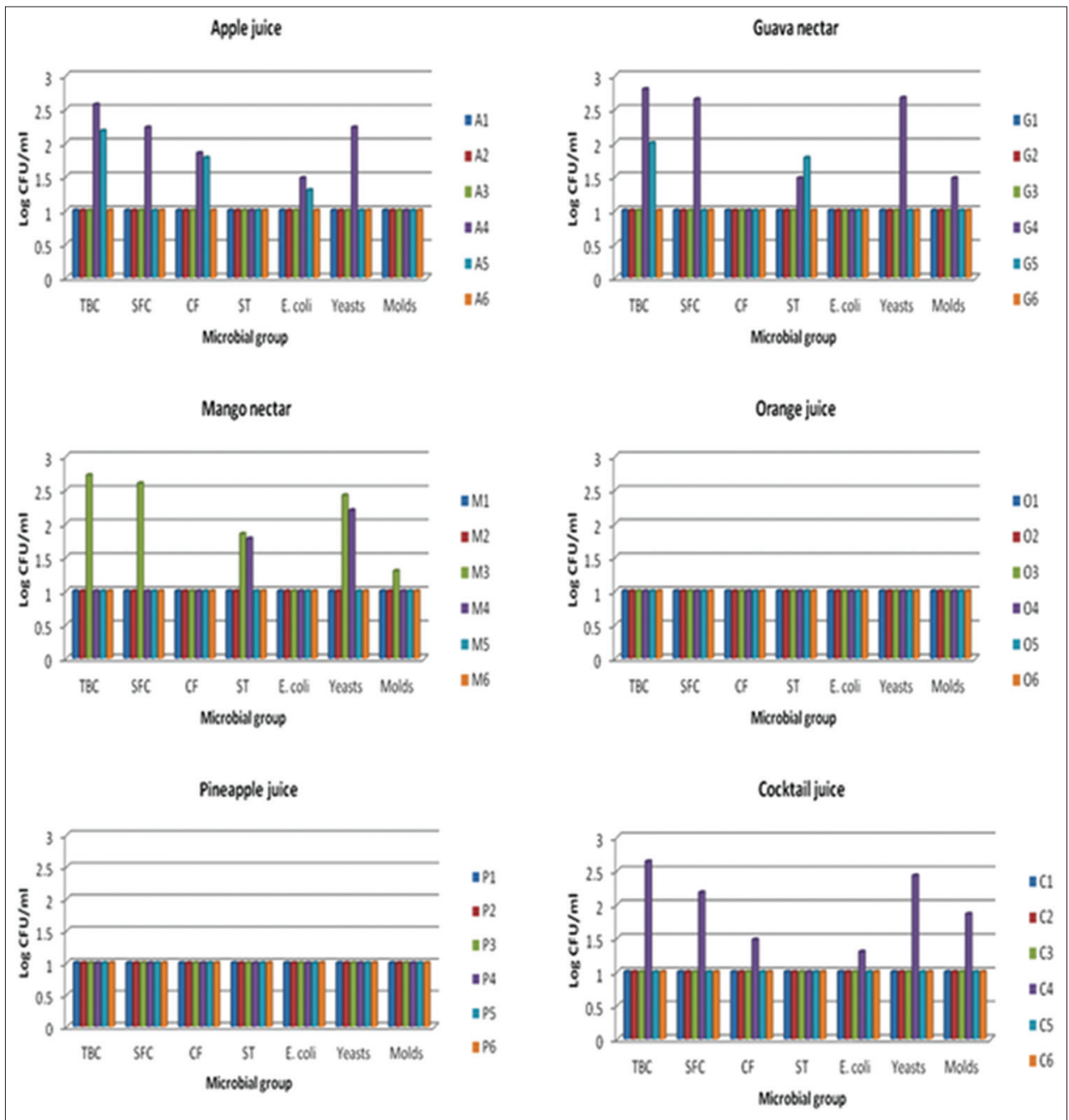

Fig 1. Microbial groups total bacterial count (TBC), sporeforming count (SFC), coliforms (CF), Staphylococcus spp. (ST), E. coli, yeasts and molds (Log CFU/ml) in fruit juices ( $\mathrm{n}=10)$.

and 4.0 and 0.26 to $0.50 \%$, respectively. These factors could be preventing the microbial association with juices production.

Table 1 shows the types of organisms isolated from different types of fruit juices. Present study showed the presence of different species of bacteria namely, Alicyclobacillus sp., Bacillus spp., E. coli, Staphylococcus spp., Candida spp. and Saccharomyces spp.

All the isolated from spore-forming belonged to as Alicyclo acidoterrestris, B. coagulans, B. licheniformis and B. mycoides from commercially available fruit juices. Their presence may pose risks to consumers' health and should not be taken for granted. These organisms can cause spoilage and economic lose, which indicates that a noticeable number of juices tested did not meet the Egyptian guidelines for the microbiological quality of juices. It should be noted that the spore-forming bacteria were detected in apple (A4), guava (G4), mango
(M3) and cocktail (C4) juices. The other samples were under the detection limit $<1.0 \log \mathrm{CFU} / \mathrm{ml}$ ) from these bacteria (Fig. 1). The highest spore-forming counts were detected in the G4 (mean counts: $2.65 \log _{10} \mathrm{CFU} / \mathrm{ml}$ in PCA agar and $2.45 \log _{10} \mathrm{CFU} / \mathrm{ml}$ in PDA agar). In the G4 sample, $75 \%$ of the isolated spore-forming bacteria were identified as Alicyclobacillus sp., Bacillus spp., E. coli, Candida spp. and Sacharomyces spp. All the isolated from spore-forming belonged to as Alicyclo acidoterrestris, B. coagulans, B. licheniformis and B. mycoides (Table 1). The results indicated that the water used for manufacturing the juices could not under control. Also, the washing step (with sanitizer) for fruits, generally considered a potential reduction step for microbial contamination, could be often not verified for its efficiency. Vantarakis, et al. (2011) reported that acidophilic microorganisms were isolated from 26 juices samples $(21.7 \%)$. This result is in agreement with those obtained by Oteiza, et al., (2011) who found that Alicyclobacillus was found in all tested fruit juices except for orange juice marketed in 


\begin{tabular}{|c|c|c|c|}
\hline Samples & $\begin{array}{l}\text { No. of } \\
\text { colonies } \\
\text { (CFU/ml) }\end{array}$ & Identified bacteria & Identified yeasts \\
\hline A4 & $\begin{array}{c}88 \times 10^{1} \\
(2.94 \pm 0.32)\end{array}$ & $\begin{array}{l}\text { Alicyclobacillus spp., } \\
\text { E. coli } \\
\text { Bacillus coagulans, } \\
\text { B. licheniformis, }\end{array}$ & $\begin{array}{l}\text { Candida spp., } \\
\text { Saccharomyces spp. }\end{array}$ \\
\hline A5 & $\begin{array}{c}23 \times 10^{1} \\
(2.36 \pm 0.12)\end{array}$ & E. coli & ND \\
\hline G4 & $\begin{array}{c}171 \times 10^{1} \\
(3.23 \pm 0.31)\end{array}$ & $\begin{array}{l}\text { Alicyclobacillus spp., } \\
\text { B. coagulans } \\
\text { B. licheniformis } \\
\text { B. mycoides } \\
\text { Staphylococcus spp. }\end{array}$ & $\begin{array}{l}\text { Candida spp., } \\
\text { Saccharomyces spp. }\end{array}$ \\
\hline G5 & $\begin{array}{c}47 \times 10^{1} \\
(2.53 \pm 0.35)\end{array}$ & Staphylococcus spp. & ND \\
\hline M3 & $\begin{array}{c}108 \times 10^{1} \\
(3.03 \pm 0.23)\end{array}$ & $\begin{array}{l}\text { Alicyclobacillus spp., } \\
\text { B. coagulans, } \\
\text { B. licheniformis } \\
\text { Staphylococcus spp. }\end{array}$ & $\begin{array}{l}\text { Candida spp., } \\
\text { Saccharomyces spp. }\end{array}$ \\
\hline M4 & $\begin{array}{c}63 \times 10^{1} \\
(2.80 \pm 0.27)\end{array}$ & Staphylococcus spp. & $\begin{array}{l}\text { Candida spp., } \\
\text { Saccharomyces spp. }\end{array}$ \\
\hline C4 & $\begin{array}{c}98 \times 10^{1} \\
(2.99 \pm 0.37)\end{array}$ & $\begin{array}{l}\text { Alicyclobacillus spp., } \\
\text { B. coagulans } \\
\text { B. licheniformis }\end{array}$ & $\begin{array}{l}\text { Candida spp., } \\
\text { Saccharomyces spp. }\end{array}$ \\
\hline
\end{tabular}

ND: Not detected. ${ }^{A}$ Values represented as average \pm standard deviation from triplicate determinations with three separately samples

Argentina. The highest percentage of positive samples was found for beetroot, strawberry, banana, peach, mango, carrot and plum juices. The percentage of positive samples for these juices ranged from $24 \%$ to 100\% (Oteiza, et al., 2011). Alicyclo acidoterrestris being the only species associated with the spoilage of fruit juices and present in South African apple juice (Wineen, 2006). These bacteria can survive, grow and sporulate despite changes in water activity, $\mathrm{pH}$ and temperature (Jaquette and Beuchat, 1998; Collado et al., 2003). With regard to the detection of these bacteria in the pasteurized fruit juices, there are two possibilities. Firstly, that they survived the pasteurization process and secondly, that contamination was post-pasteurization as demonstrated by Walker and Phillips, 2007, in UK, during their studies on the growth of Propionibacterium cyclohexanicum in fruit juices and its survival following elevated temperature treatments. Ghenghesh, et al., (2005) recorded that Candida albicans, Candida spp. and other yeasts were found at levels $18(12.3 \%), 109(74.7 \%)$ and 85 (58\%) in the juices sold in Tripoli, Libya, respectively. $C$. albicans can cause serious disease in humans (Chihab et al., 2004). Further analysis of commercially sold fruit juices should be done. Regulation in the issuance of permits to produce and sell these products should be under strict quality control to reduce and mitigate exposure to harmful microbes. Recently, Parish (2009) mentioned that certain yeasts-molds and bacteria may survive at low $\mathrm{pH}$, processing and preservation conditions to cause spoilage problems in fruit juice products. Thus, spoilage of fruit juices depends on fruit quality, holding and handling conditions, grading, processing conditions, cleaning/sanitation efficiency, and temperature of product storage.

\section{Physicochemical indicators in fruit juices samples}

To evaluate the physicochemical properties after manufacturing and during their shelf-life, the $\mathrm{pH}$, titratable acidity, total soluble solids (TSS) and total sugars as well as colour measurements of the apple, orange, guava, pineapple, mango and cocktail juices and nectars were measured (Tables $2 \& 3$ ). The $\mathrm{pH}$ of the tested juices ranged from 2.7 (apple juice) to 4.1 (guava and mango nectars) as shown in Table 2 . The average $\mathrm{pH}$ of apple, guava, mango, orange, pineapple and cocktail juices was $2.96,3.80,3.93,3.33,3.68$ and 3.73 , respectively. There was no significant difference in $\mathrm{pH}$ value between the same juices compared between all companies. Similar results have been reported by Ghenghesh, et al., (2005) who found that the $\mathrm{pH}$ of juices examined ranged between 3.09 and $6.24($ mean $=3.82)$.

In this study, the values of titratable acidity of the juices ranged from 0.14 (guava nectar) to 0.50 (orange nectar). The titratable acidity was not significantly different between all the brands producing the same juice. The total sugar of tested juices ranged from 11.0 (mango nectar) to 25.0 (guava nectar).

The results of TSS are displayed in Table 2 and were expressed in ${ }^{\circ}$ Brix. The TSS of the tested juices ranged from $10.4^{\circ}$ Brix (cocktail juice) to $15.0^{\circ}$ Brix (mango nectar). There was no significant difference in total soluble solids for the same fruit juices compared between all brands. Hence, this shows that all brands flow the same methods of production and these methods did not affect the total soluble solids of the similar juice produced by different brands.

The measurement of colour is important for the quality assessment of juice. The $L$ value measures the lightness of the juice whereby values nearer to zero indicate the darker the juice $(0=$ black, $100=$ white $)$. In this study, there was significant different between the similar juice producing from different brands in $\mathrm{L}$ value as shown in Table 3. The $\mathrm{L}$ value of apple juice ranged from $3.71 \pm 0.35$ (A3) to $6.10 \pm 0.33$ (A2), guava juice from $49.53 \pm 0.31$ (G3) to $64.21 \pm 0.43$ (G2), mango juice from $23.46 \pm 0.35$ (M4) to $48.1 \pm 0.39$ (M2), pineapple juice from $22.96 \pm 0.39$ (P6) to $30.90 \pm 0.32$ (P1), orange juice $27.58 \pm 0.35$ (O4) to $50.72 \pm 0.34(\mathrm{O} 2)$ and in cocktail juice from 15.61 \pm 0.31 
Table 2: Physiochemical characteristics of fruit juices samples (mean \pm SD) ${ }^{A}$

\begin{tabular}{|c|c|c|c|c|c|c|}
\hline Samples & Type & Fruit & $\mathrm{pH}$ & Acidity (\%) & TSS ( ${ }^{\circ}$ Brix) & Total sugar (\%) \\
\hline $\mathrm{A} 1$ & Juice & Apple & $2.7 \pm 0.11$ & $0.47 \pm 0.14$ & $14.0 \pm 0.13$ & $17 \pm 0.52$ \\
\hline A2 & Juice & Apple & $3.1 \pm 0.12$ & $0.38 \pm 0.23$ & $12.0 \pm 0.13$ & $19 \pm 0.61$ \\
\hline A3 & Juice & Apple & $3.0 \pm 0.11$ & $0.32 \pm 0.32$ & $13.2 \pm 0.12$ & $15 \pm 0.61$ \\
\hline A4 & Juice & Apple & $3.3 \pm 0.13$ & $0.32 \pm 0.33$ & $13.1 \pm 0.14$ & $16 \pm 0.41$ \\
\hline A5 & Juice & Apple & $2.9 \pm 0.41$ & $0.34 \pm 0.11$ & $14.3 \pm 0.14$ & $20 \pm 0.71$ \\
\hline A6 & Juice & Apple & $2.8 \pm 0.14$ & $0.28 \pm 0.21$ & $14.2 \pm 0.15$ & $15 \pm 0.91$ \\
\hline G1 & Nectar & Guava & $3.6 \pm 0.13$ & $0.14 \pm 0.21$ & $13.0 \pm 0.13$ & $23 \pm 0.41$ \\
\hline G2 & Nectar & Guava & $4.1 \pm 0.16$ & $0.19 \pm 0.11$ & $12.0 \pm 0.14$ & $22 \pm 0.71$ \\
\hline G3 & Nectar & Guava & $3.8 \pm 0.13$ & $0.20 \pm 0.13$ & $13.0 \pm 0.14$ & $25 \pm 0.45$ \\
\hline G4 & Nectar & Guava & $3.8 \pm 0.12$ & $0.22 \pm 0.13$ & $13.0 \pm 0.11$ & $21 \pm 0.45$ \\
\hline G5 & Nectar & Guava & $3.8 \pm 0.14$ & $0.21 \pm 0.09$ & $14.0 \pm 0.19$ & $20 \pm 0.87$ \\
\hline G6 & Nectar & Guava & $3.7 \pm 0.15$ & $0.23 \pm 0.14$ & $14.0 \pm 0.13$ & $22 \pm 0.76$ \\
\hline M1 & Nectar & Mango & $3.7 \pm 0.12$ & $0.22 \pm 0.18$ & $15.2 \pm 0.16$ & $11 \pm 0.54$ \\
\hline M2 & Nectar & Mango & $4.1 \pm 0.12$ & $0.23 \pm 0.16$ & $13.2 \pm 0.11$ & $13 \pm 0.45$ \\
\hline M3 & Nectar & Mango & $3.9 \pm 0.11$ & $0.21 \pm 0.14$ & $11.0 \pm 0.17$ & $12 \pm 0.73$ \\
\hline M4 & Nectar & Mango & $4.0 \pm 0.10$ & $0.24 \pm 0.13$ & $14.0 \pm 0.12$ & $12 \pm 0.24$ \\
\hline M5 & Nectar & Mango & $4.1 \pm 0.12$ & $0.23 \pm 0.15$ & $15.0 \pm 0.14$ & $13 \pm 0.74$ \\
\hline M6 & Nectar & Mango & $3.8 \pm 0.16$ & $0.22 \pm 0.16$ & $15.1 \pm 0.17$ & $11 \pm 0.64$ \\
\hline P1 & Juice & Pineapple & $3.9 \pm 0.15$ & $0.29 \pm 0.12$ & $12.0 \pm 0.14$ & $15 \pm 0.65$ \\
\hline P2 & Juice & Pineapple & $3.8 \pm 0.14$ & $0.32 \pm 0.16$ & $12.0 \pm 0.14$ & $14 \pm 0.61$ \\
\hline P3 & Juice & Pineapple & $3.6 \pm 0.13$ & $0.31 \pm 0.14$ & $13.0 \pm 0.41$ & $16 \pm 0.67$ \\
\hline P4 & Juice & Pineapple & $3.5 \pm 0.14$ & $0.34 \pm 0.12$ & $11.0 \pm 0.16$ & $14 \pm 0.69$ \\
\hline P5 & Juice & Pineapple & $3.7 \pm 0.13$ & $0.29 \pm 0.16$ & $13.0 \pm 0.17$ & $15 \pm 0.71$ \\
\hline P6 & Juice & Pineapple & $3.8 \pm 0.14$ & $0.26 \pm 0.21$ & $13.0 \pm 0.12$ & $15 \pm 0.65$ \\
\hline 01 & Juice & Orange & $2.9 \pm 0.12$ & $0.46 \pm 0.15$ & $12.2 \pm 0.17$ & $15 \pm 0.81$ \\
\hline $\mathrm{O} 2$ & Juice & Orange & $3.2 \pm 0.15$ & $0.50 \pm 0.14$ & $11.0 \pm 0.11$ & $14 \pm 0.43$ \\
\hline $\mathrm{O} 3$ & Juice & Orange & $3.1 \pm 0.18$ & $0.50 \pm 0.18$ & $13.0 \pm 0.18$ & $13 \pm 0.63$ \\
\hline $\mathrm{O}$ & Juice & Orange & $3.4 \pm 0.13$ & $0.33 \pm 0.13$ & $14.0 \pm 0.12$ & $15 \pm 0.6$ \\
\hline O5 & Juice & Orange & $3.3 \pm 0.14$ & $0.45 \pm 0.15$ & $11.0 \pm 0.14$ & $16 \pm 0.45$ \\
\hline O6 & Juice & Orange & $3.6 \pm 0.13$ & $0.43 \pm 0.13$ & $14.3 \pm 0.17$ & $14 \pm 0.65$ \\
\hline $\mathrm{C} 1$ & Juice & Cocktail & $3.3 \pm 0.12$ & $0.33 \pm 0.16$ & $12.0 \pm 0.19$ & $11 \pm 0.82$ \\
\hline $\mathrm{C} 2$ & Juice & Cocktail & $3.9 \pm 0.12$ & $0.47 \pm 0.11$ & $12.0 \pm 0.11$ & $11 \pm 0.54$ \\
\hline C3 & Nectar & Cocktail & $3.8 \pm 0.11$ & $0.23 \pm 0.13$ & $12.4 \pm 0.16$ & $12 \pm 0.54$ \\
\hline $\mathrm{C} 4$ & Nectar & Cocktail & $3.7 \pm 0.10$ & $0.23 \pm 0.15$ & $10.4 \pm 0.17$ & $11 \pm 0.34$ \\
\hline C5 & Juice & Cocktail & $3.9 \pm 0.19$ & $0.28 \pm 0.11$ & $11.2 \pm 0.19$ & $13 \pm 0.33$ \\
\hline C6 & Juice & Cocktail & $4.0 \pm 0.15$ & $0.30 \pm 0.18$ & $14.2 \pm 0.12$ & $11 \pm 0.38$ \\
\hline
\end{tabular}

AValues represented as average \pm standard deviation from triplicate determinations with three separately samples

(C6) to $46.56 \pm 0.36$ (C2). Hence, from this study it can be said that the different brands and different ways for sterilizing juices lead to varying lightness properties. However, all samples tested for colour still maintain the colour quality of the juices. The same trend was observed in the *(redness) and $\mathrm{b}^{*}$ (yellowness) values in juices samples. In general, the color intensity of the tested samples as measured by Hunter $\mathrm{L}^{*}, \mathrm{a}^{*}$ and $\mathrm{b}^{*}$ was strongly influenced by juice treatments in each company during processing and it can be seen that as brightness ( $\mathrm{L}^{*}$-values) decreased, redness (a*-values) increased and yellowness ( $\mathrm{b}^{*}$-values) decreased in all samples, and overall color differences depends on the type of fruit. The hue angle and chroma are colour properties that are related to the*(redness) and $b^{*}$ (yellowness). The slight varying was observed in chroma for the similar juice but producing from different brands.

\section{CONCLUSIONS}

In general, based on the microbiological (TBC, SFC, coliforms, E. coli, Staphylococcus and yeasts \& molds) and physico-chemical analyses $(\mathrm{pH}$, titratable acidity, total soluble solids, total sugars and colour), all the similar fruit juices of the same type from different brands had similar physicochemical characteristics. However, microbiological characteristics in some brands did not fulfill the Egyptian guidelines for the microbiological quality of juice, due to the detection of spore-forming bacteria. Many of these organisms can cause spoilage and diseases. Hence, Alicyclobacillus as spoilage organism, and it should be involved into the Egyptian guidelines for microbiological quality of juices, due to it provides a better hygiene indicator for juice producing in the countries with climate changes and varying in temperatures. 
Table 3: Color of fruit juices samples $(n=10)$

\begin{tabular}{lccc}
\hline Samples & \multicolumn{3}{c}{ Color } \\
\cline { 2 - 4 } & $\mathbf{L}^{*}$ & $\mathbf{a}^{*}$ & $\mathbf{b}^{*}$ \\
\hline A1 & $5.46 \pm 0.34$ & $0.67 \pm 0.22$ & $2.19 \pm 0.13$ \\
A2 & $6.10 \pm 0.33$ & $0.08 \pm 0.21$ & $2.98 \pm 0.13$ \\
A3 & $3.71 \pm 0.35$ & $1.03 \pm 0.23$ & $2.41 \pm 0.14$ \\
A4 & $4.61 \pm 0.37$ & $-0.48 \pm 0.00$ & $2.67 \pm 0.15$ \\
A5 & $4.13 \pm 0.45$ & $0.90 \pm 0.23$ & $2.57 \pm 0.11$ \\
A6 & $6.06 \pm 0.32$ & $0.33 \pm 0.24$ & $2.89 \pm 0.10$ \\
G1 & $53.33 \pm 0.39$ & $-3.40 \pm 0.00$ & $9.16 \pm 0.13$ \\
G2 & $64.21 \pm 0.43$ & $-1.73 \pm 0.00$ & $15.70 \pm 0.17$ \\
G3 & $49.53 \pm 0.31$ & $-2.88 \pm 0.00$ & $13.86 \pm 0.15$ \\
G4 & $56.87 \pm 0.33$ & $-2.65 \pm 0.00$ & $14.87 \pm 0.19$ \\
G5 & $57.87 \pm 0.43$ & $-2.77 \pm 0.00$ & $15.74 \pm 0.21$ \\
G6 & $55.81 \pm 0.33$ & $-2.69 \pm 0.00$ & $13.89 \pm 0.26$ \\
M1 & $34.31 \pm 0.33$ & $1.54 \pm 0.24$ & $19.64 \pm 0.25$ \\
M2 & $48.10 \pm 0.39$ & $6.11 \pm 0.43$ & $29.36 \pm 0.37$ \\
M3 & $33.54 \pm 0.36$ & $4.87 \pm 0.32$ & $24.32 \pm 0.36$ \\
M4 & $23.46 \pm 0.35$ & $-1.62 \pm 0.00$ & $12.42 \pm 0.22$ \\
M5 & $41.30 \pm 0.33$ & $7.21 \pm 0.54$ & $25.33 \pm 0.31$ \\
M6 & $35.45 \pm 0.32$ & $3.86 \pm 0.31$ & $21.68 \pm 0.32$ \\
P1 & $30.90 \pm 0.32$ & $-2.40 \pm 0.00$ & $9.80 \pm 0.21$ \\
P2 & $29.84 \pm 0.33$ & $-0.49 \pm 0.00$ & $13.77 \pm 0.36$ \\
P3 & $25.97 \pm 0.23$ & $-3.78 \pm 0000$ & $7.21 \pm 0.23$ \\
P4 & $26.80 \pm 0.33$ & $2.54 \pm 0.32$ & $6.67 \pm 0.26$ \\
P5 & $26.12 \pm 0.23$ & $3.06 \pm 0.22$ & $9.24 \pm 0.23$ \\
P6 & $22.96 \pm 0.38$ & $-1.96 \pm 000$ & $4.64 \pm 0.11$ \\
O1 & $42.63 \pm 0.31$ & $-3.44 \pm 0.00$ & $21.02 \pm 0.42$ \\
O2 & $50.72 \pm 0.34$ & $1.07 \pm 0.12$ & $29.28 \pm 0.54$ \\
O3 & $29.25 \pm 0.36$ & $-0.41 \pm 00$ & $16.91 \pm 0.16$ \\
O4 & $27.58 \pm 0.35$ & $10.24 \pm 0.52$ & $17.27 \pm 0.19$ \\
O5 & $33.75 \pm 0.34$ & $0.65 \pm 0.11$ & $19.19 \pm 0.26$ \\
O6 & $26.98 \pm 0.33$ & $-2.14 \pm 0.00$ & $12.99 \pm 0.43$ \\
C1 & $25.83 \pm 0.34$ & $1.50 \pm 0.26$ & $14.94 \pm 0.22$ \\
C2 & $46.56 \pm 0.36$ & $3.84 \pm 0.23$ & $25.38 \pm 0.21$ \\
C3 & $16.64 \pm 0.38$ & $10.42 \pm 0.32$ & $5.40 \pm 0.21$ \\
C4 & $34.65 \pm 0.34$ & $5.34 \pm 0.22$ & $4.11 \pm 0.32$ \\
C5 & $29.33 \pm 0.38$ & $21.64 \pm 0.65$ & $3.35 \pm 0.22$ \\
C6 & $15.61 \pm 0.31$ & $15.03 \pm 0.43$ & $2.63 \pm 0.12$ \\
\hline & & &
\end{tabular}

\section{Author contributions}

S.A.M.M. is the principal author of this work and design of study. He has made major contributions to this article in sampling, microbiological analysis of juices samples, counting, isolation, identification of microbes etc.). G.A.E.S. was involved in physicochemical analysis of juices samples.

\section{REFERENCES}

Amato, D. 1999. The mineral content of bottled water and other beverages: Implications for health and disease. Am. J. Med. 105: $125-130$

AOAC. 1997. Official Methods of Analysis, $13^{\text {th }}$ ed. AOAC, Washington, D. C., USA.

APHA. 2001. Compendium of Methods for the Microbiological Examination of Foods, $4^{\text {th }}$ ed. American Public Health Association, Washington, D. C.
Bendich, A., L. J. Machlin, O. Scandurra, G. W. Burton and D. D. D. Wayner. 1986. The antioxidant role of vitamin C. Adv Free Radical. Biol. Med. 2: 419-444.

Bernalte, M. J., E. Sabio, M. T. Hernandez and C. Gervasini. 2003. Influence of storage delay on quality 'Van' sweet cherry. Post. Biol. Technol. 28: 303-312.

Buchanan, R. L., S. G. Edelson, K. Snipes and G. Boyd. 1998. Inactivation of Escherichia coli 0157: $\mathrm{H} 7$ in apple juice by irradiation. Appl. Environ. Microbiol. 64(11): 4533-4535.

Carlin, F. 2011. Origin of bacterial spores contaminating foods. Food Microbiol. 28(2): 177-182.

CDC. 1997. Outbreaks of Escherichia coli O157: H7 Infection and Cryptosporidiosis Associated with Drinking Unpasteurized Apple Cider -- Connecticut and New York, October, 1996, 46(01): 4-8.

Chang, S. S. and D. H. Kang. 2004. Alicyclobacillus spp. in the fruit juice industry: History, characteristics, and current isolation/ detection procedures. Crit. Rev. Microbiol. 30(2): 55-74.

Chihab, C. W., A. S. Alaoui and M. Amar. 2004. Chryseomonas luteola identified as a source of serious infection in a Moroccan hospital. J. Clin. Microbiol. 42: 1837-1839.

Christen, L. G., M. P. Davidson, S. J. McAllister and A. L. Roth. 1992. Coliform and other indicator bacteria. In: T. R. Marshall (Ed.), Standard Method for the Examination of Dairy Product, $16^{\text {th }}$ ed. American Public Health Association, Washington, D. C.

Collado, J., A. Fernandez, L. M. Cunha, M. J. Ocio and A. Martinez, 2003. Improved model based on the Weibull distribution to describe the combine effect of $\mathrm{pH}$ and temperature on the heat resistance of Bacillus cereus in carrot juice. J. Food Prot. 66(6): 978-984.

Daramola, B. and O. A. Asunni. 2007. Preparation, physiochemical and sensory assessment of pawpaw red ginger food drink. American-Eurasian J. Sci. Res. 2(2): 101-105.

Dey, B. P. and C. P. Lattuada. 1998. Microbiology Laboratory Guidebook, $3^{\text {rd }}$ ed., Ch. 12. United States Department of Agriculture Food Safety and Inspection Service office of Public Health and Science Microbiology Division, Washington, D. C.

Durak, M. Z., J. J. Churey, M. D. Danyluk and R. W. Worobo. 2010. Identification and haplotype distribution of Alicyclobacillus spp. from different juices and beverages. Int. J. Food Microbiol. 142: 286-291.

EU Regulation' means Commission Regulation (EC) No. 2073/2005 of 15 November $2005^{2}$, as amended by Commission Regulation (EC) No. 1441/2007 of 5 December $2007^{3}$, Commission Regulation (EU) No. 365/2010 of 28 April 20104 , Commission Regulation (EU) No. 1086/2011 of 27 October $2011^{5}$ and Commission Regulation (EU) No. 209/2013 of 11 March 2013 .

FDA. 2001. Food and Drug Administration. FDA Publishes Final Rule to Increase Safety of Fruit and Vegetable Juices. [Last retrieved on 2011 Dec 17].

Ghenghesh, K. S., K. Belhaj, W. B. El-Amin, S. E. El-Nefathi and A. Zalmum. 2005. Microbiological quality of fruit juices sold in Tripoli-Libya. Food Con. 16: 855-858.

Holt, J.G., N. R. Krieg, P. H. A. Sneath, J. T. Staley, S. T. Williams and S. Bergey. (1994). Manual of Determinative Bacteriology, $9^{\text {th }}$ ed. Willaims and Willkins, Baltimore, USA. Available from: http:// www.f gov/bbsltopicsMEWS/2010/NEWOO749.html.

Jaquette, C. B. and L. R. Beuchat. 1998. Survival and growth of psychotrophic Bacillus cereus in dry and reconstituted infant rice cereal. J. Food Prot. 61: 1629-1635.

Komitopoulou, E., I. S. Boziaris, E. A. Davies, J. Delves-Broughton and M. R. Adams. 1999. Alicyclobacillus acidoterrestris in fruit juices and its control by nisin. Int. J. Food Sci. Technol. 34: 81-85. 
Kurtzmann, C. P., C. J. Robnett and D. Yarrow. 2001. Three new species of Candida from apple cider: C. Anglica, C. cidri, and C. pomicola. Antoinie Van Leeuwenhoek. 80(3-4): 237-244.

Mclntyre, S., J. Y. Ikawa, N. Parkinson, J. Haglund and J. Lee. 1995. Characteristics of an acidophilic Bacillus strain isolated from shelf-stable juices. J. Food Prot. 58: 319-321.

Mendoza, S., L. Montemayor, L. A. Boscan and J. A. Barriero. 1982. Microflora in pasteurized fruit juices in Venezuela. Arch. Latinoam. Nutr. 32(3): 617-629.

Mishra, S. and N. Behera. (2008). Amylase activity of a starch degrading bacteria isolated from soil receiving kitchen wastes. Afr. J. Biotechnol. 7: 326-333.

Ndife, J., D. Awogbenja and U. Zakari. 2013. Comparative evaluation of the nutritional and sensory quality of different brands of orange-juice in Nigerian market. Afr. J. Food Sci. 7(12): 479-484.

Oteiza, J. M., A. Ares, A. S. Sant'Ana, S. Soto and L. Giannuzzi. 2011. Use of a multivariate approach to assess the incidence of Alicyclobacillus spp. in concentrate fruit juices marketed in Argentina: Results of a 14-year survey. Int. J. Food Microbiol. 151: 229-234.

Parish, M. E. 2009. Food safety issues and the microbiology of fruit beverages and bottled water. In: Heredia, N., I. Wesley and S. Garcia (Eds.), Microbiologically Safe Foods, John Wiley \& Sons, Inc., New York.

Parish, M. E. and D. P. Higgins. 1989. Yeasts and moulds isolated from spoiling citrus products. J. Food Prot. 52: 261-263.

Rhodehamel, G., H. L. Bruce, D. B. Hunter, V. R. Parreira, R. R. Kulkarni, Y. F. Jiang. J. F. Prescott and P. Boerlin. (1998). Multilocus sequence typing analysis of Clostridium perfringens isolates from necrotic enteritis outbreaks in broiler chicken populations. Department of Pathobiology, Ontario
Veterinary College, University of Guelph, Guelph, Ontario, Canada.

Splittstosser, D. F., J. J. Churey, and Lee, C. Y. 1994. Growth characteristics of aciduric spore-forming bacilli isolated from fruit juices. J. Food Prot. 57: 1080-1083.

Steyn, C. E., M. Cameron and R. C. Wittuhn. 2011. Occurrence of Alicyclobacillus in the fruit processing environment $-\mathrm{A}$ review. Int. J. Food Microbiol. 147: 1-11.

Tournas, V. H., J. Heeres and L. Burgess. 2006. Moulds and yeasts in fruit salads and fruit juices. Food Microbiol. 23: 684-688.

USDA-FSIS. 1996. Pathogen Reduction: Hazard Analysis and Critical Control Point (HACCP) Systems," Title 9 of the Code of Federal Regulations, Part 304.

Vantarakis, A., M. Affifi, P. Kokkinos, M. Tsibouxi and M. Papapetropoulou. 2011. Occurrence of microorganisms of public health and spoilage significance in fruit juices sold in retail markets in Greece. Anaerobe. 17: 288-291.

Walker, M. and C. A. Phillips. 2007. The growth of Propionbacterium cyclohexanicum in fruit juices and its survival following elevated temperature treatments. Food Microbiol. 24: 313-318.

Walker, M. and C. A. Phillips. 2008. Alicyclobacillus acidoterrestris: An increasing threat to the fruit juice industry? Int. J. Food Sci. Technol. 43: 250-260.

Walls, I. and R. Chuyate. 1998. Alicyclobacillus - Historical perspective and preliminary characterization study. Dairy Food Environ. Sanit. 18: 499-503.

Wineen, D. 2006. Detection and isolation of thermophilic acidophilic bacteria from fuit juices. Thesis (M. Sc. Food Sc.) Food Science Department - Faculty of AgriScience, University of Stellenbosch, South Africa. Available from: http://www.hdl. handle.net/10019.1/3016 